\title{
Domestic Violence: Is the Sri Lankan Woman Still Trapped in the Private Sphere?
}

\author{
Sunethra M. E. Goonetilleke ${ }^{1}$ \\ Department of Legal Studies, The Open University of Sri Lanka
}

\begin{abstract}
Domestic violence is a phenomenon of which women are predominantly the victims. For a long period of time, legal regimes relegated such violence into the private or family sphere and refused to provide any relief to its victims.
\end{abstract}

The aim of this paper is to trace how domestic violence gradually evolved from this early position, to the modern perception of it as a violation of women's rights demanding state intervention. For this purpose the paper will begin by examining the international treaties and conventions containing provisions relevant to domestic violence such as the Universal Declaration of Human Rights, International Covenant on Civil and Political Rights, the International Covenant on Economic, Social and Cultural Rights and the Convention on the Elimination of All Forms of Discrimination against Women.

It will then proceed to identify the extent to which Sri Lanka, which is bound by these international instruments, has taken steps to incorporate treaty obligations into domestic legislation. The scope and role of the Prevention of Domestic Violence Act No 34 of 2005, which is seen as the key attempt of the state to combat domestic violence in Sri Lanka, will then be studied in order to identify the extent to which it provides a viable solution to those confronted with domestic violence and make homes safe spaces for women in Sri Lanka.

Keywords: Prevention of Domestic Violence Act, domestic violence; protection orders, feminism.

${ }^{1}$ Correspondence should be addressed to Ms. S. M. E. Goonetilleke, Department of Legal Studies, The Open University of Sri Lanka, Nawala Nugegoda.

(Email: mailforsunethra@gmail.com) 


\section{Introduction}

\section{The Nature and Scope of the Study}

Domestic violence has long been a phenomenon which occurred behind closed doors. For generations of women, violence was an inescapable part of family life for which stoic endurance was the only socially acceptable solution. As McColgan (1993) citing Tomie states, The characterisation of the family as private can be seen ... to have operated to create a sphere in which women are isolated, rendered invisible and placed beyond the protection of the legal system.'

Early law did not recognise the concept of domestic violence. Indeed as stated by Lord Denning in Davies $v$ Johnson (1979) in UK '...By the common law a husband was allowed to beat his wife so long as he did it with a stick no bigger than his thumb'. It was only through the sustained efforts of the feminist movement and after a long period of time that a definition for domestic violence and a need for state intervention to prevent such violence evolved.

A study of key international instruments reveals how domestic violence emerged from the purely private family sphere to which it long remained relegated and into which law makers refused to venture, to the modern perception of it as a violation demanding state intervention.Today a clear understanding of domestic violence can be derived from these international conventions, as will be seen from the discussion below. These can be summarized by the definition (which although it does not apply in Sri Lanka and is of limited legal applicability as it originates from the Council of Europe is used as it is a comprehensive one) of the Council of Europe Convention on Preventing and Combating Violence against Women and Domestic Violence (The Istanbul Convention) of $11^{\text {th }}$ May 2011, which defines domestic violence in Article 3 (b) as follows; "domestic violence" shall mean all acts of physical, sexual, psychological or economic violence that occur within the family or domestic unit or between former or current spouses or partners, whether or not the perpetrator shares or has shared the same residence with the victim'.

The main objective of this research is to study the Sri Lankan legal position on domestic violence, with special emphasis on the extent to which Sri Lanka has succeeded in effecting its transition from the private sphere to the public one. 
The paper will begin by examining the international treaties and conventions relevant to domestic violence such as the Universal Declaration of Human Rights (UDHR), International Covenant on Civil and Political Rights (ICCPR), the International Covenant on Economic, Social and Cultural Rights (ICESCR) and the Convention on the Elimination of All Forms of Discrimination Against Women (CEDAW) in order to trace the manner in which domestic violence has gradually become a state responsibility.

The paper will then proceed to examine how Sri Lankan law has responded to these international developments, by focusing on the Prevention of Domestic Violence Act No 34 of 2005 which is seen as one of the key attempts of the state to combat domestic violence in Sri Lanka. This landmark law is hailed as the law which paved the way for domestic violence to be recognized as an issue entitled to legal redress. However, the extent to which it provides a viable solution to those confronted with domestic violence is, the author believes, a moot point. Therefore, this paper endeavours to examine the scope of this law and its role in combating violence and making homes safe spaces for women in Sri Lanka by removing the issue from the private domain and placing it firmly within the public one.

\section{Theoretical Framework}

This study is approached from a feminist perspective. Feminism according to Clare Dalton (1987) is a 'range of committed inquiry and activity, dedicated first to describing women's subordinationexploring its nature and extent; dedicated second to asking both how-through what mechanisms, and why - for what complex and interwoven reasons - women continue to occupy that position; and dedicated third to change.' Feminist's postulate that the politics of law is to perpetuate patriarchal dominance and that the public, private division is created to maintain that status quo. Lacey (1998) argues that The ideology of the public private dichotomy allows governments to clean its hands of any responsibility for the state of the private world because as Freeman (2008) comments, defining the family as 'private' places it outside the authority of the state'.

Domestic violence has been historically considered to fall within the private domain, and outside state authority. Thus, the recognition of the gravity of domestic violence and the need to address it has required a battle to bring it out of this private domain. The author believes that the development of feminist jurisprudence has played a 
key role in this battle and that its success can be traced through the international conventions relevant to this area. The focus of this study is to examine the extent to which Sri Lankan law has succeeded in removing the barriers to state intervention in order to protect women against domestic violence.

\section{Methodology}

This study is normative in nature and is based on documentary analysis. The paper will first study the international instruments and trace the gradual increase in emphasis on domestic violence as something more than a private matter concerning those within the home. The paper will then focus on the Sri Lankan law or more specifically the Prevention of Domestic Violence Act in order to analyze the extent to which Sri Lankan law has succeeded in keeping abreast with the changes on the international front.

\section{Discussion}

The presentation of the discussion will be two fold. The first part will deal with the international instruments and the second will focus on the Sri Lankan context.

\section{International Instruments}

Lawmakers have long been reluctant to intervene in issues of domestic violence and have, in fact, recognized the right of the husband to 'give his wife moderate correction' (Blackstone 1765) and the necessity of the wife to suffer rape 'because the wife has given herself up in this kind unto her husband' (Hale 1738). However, the following analysis of international instruments shows that domestic violence has been identified as a violation of human rights from the earliest recognition of the concept of human rights and that with the passage of time; liability has been imposed on states to combat it.

\section{The Universal Declaration of Human Rights, International Covenant on Civil and Political Rights and International Covenant on Economic Social and Cultural Rights}

The right of a person to live a family life free of violence can be traced back to many international documents. The Universal Declaration of Human Rights of 1948 in its preamble states, '...(that) the peoples of the United Nations have in the Charter reaffirmed their faith in fundamental human rights, in the dignity and worth of 
the human person and in the equal rights of men and women'. Further, Article 1 recognizes that 'All human beings are born free and equal in dignity and rights' while Article 2 guarantees the rights and freedoms in the declaration to everyone without any distinction. Article 3 Recognizes the right to life, liberty and security of person while a similar provision to this exists in Article 6 of the International Covenant on Civil and Political Rights 1966. According to Article 5 of the UDHR (and also Article 7 of the ICCPR) 'no one shall be subject to torture or to cruel, inhuman and degrading treatment or punishment'. Further according to Article 7 of the UDHR (and Article 16 of the ICCPR) 'All are equal before the law and are entitled without any discrimination to equal protection of the law' and the rights recognised by the declaration. Thus, the UDHR and the ICCPR contain provisions which deal with equality and focus on the dignity of the person, both of which militate against the use of violence.

Article 16 of the UDHR ensures equal rights to men and women during marriage and at its dissolution while Article 23 of the ICCPR includes equal responsibilities as well. According to Article 25, (1) of the UDHR; everyone has the right to a standard of living adequate for the health and well-being of himself and of his family, including food, clothing, housing and medical care and necessary social services ...', while motherhood and childhood are entitled to special care and assistance. The International Covenant on Economic Social and Cultural Rights1966 (ICESCR) which entered into force in 1976, also recognises that special protection should be accorded to mothers, during, and a reasonable period after, childbirth (Article 10) and the right to highest attainable standard of physical and mental health (Article 12). These provisions clearly envisage a family unit where the spouses are on an equal footing and free from physical, psychological or economic violence.

By virtue of Article 3 of the ICCPR and Article 3 of the ICESCR, member states undertake to ensure the civil, political, economic, social and cultural rights set out in the respective covenants. These provisions could be viewed as empowering states to eradicate domestic violence especially in the form of physical and economic violence and arguably out of the private and into the public domain.

Thus, the UDHR, ICCPR and ICESCR recognised a range of rights which were equally available to men and women, thereby tacitly recognising that domestic violence by depriving men or women of these rights was a violation of their basic human rights. 


\section{The Convention on the Elimination of All Forms of Discrimination against Women}

The first international document which focused exclusively on women and has since paved the way for significant improvement of the position of women is the Convention on the Elimination of All Forms of Discrimination against Women 1979 which entered into force in 1982. Article 5 of CEDAW requires States to modify the social and cultural patterns of conduct of men and women, with a view to achieving the elimination of prejudices and customary and all other practices which are based on the idea of the inferiority or the superiority of either of the sexes or on stereotyped roles for men and women' as well as ensure family education to promote understanding of maternity as a social function and the common responsibility of men and women in upbringing and development of children. Further Article 16 obliges member states to take all appropriate measures to eliminate discrimination against women in all matters relating to marriage and family relations and ensure among other things equal rights and responsibilities as parents and in deciding the number and spacing of children.

The above provisions thus bind Signatories to CEDAW to actively take steps to eradicate the major causes of domestic violence. It would then appear that by these requirements of state intervention, CEDAW has envisaged dissolution of the private, public divide behind which most perpetrators of domestic violence take refuge.

\section{The Declaration on the Elimination of All Forms of Violence against Women}

CEDAW was followed in 1993 by the Declaration on the Elimination of All Forms of Violence against Women. This declaration, in its lengthy preamble, identifies the various conventions, such as the UNDHR, ICCPR, ICESCR and CEDAW which set out articles dealing with equality between the sexes, and recognizes that violence against women prevents the achievement of this equality. The declaration adopts the feminist theory in the preamble 'Recognizing that violence against women is a manifestation of historically unequal power relations between men and women, which have led to domination over and discrimination against women by men and to the prevention of the full advancement of women, and that violence against women is one of the crucial social mechanisms by which women are forced into a subordinate position compared with men...' (This view also finds expression in Article 118 of the Beijing 
Declaration discussed below). It points to the Economic and Social Council resolution (1990) which recognized that violence against women in the family and society was pervasive and cut across lines of income, class and culture and had to be matched by urgent and effective steps to eliminate its incidence and also focuses on the Economic and Social Council resolution (1991) which recommended the development of a framework for an international instrument that would address explicitly the issue of violence against women. The Declaration consists of six Articles, of which 1 and 2 set out a definition for violence, 3 discusses the rights of women and Articles 4 and 5 deal with State and UN obligations to eliminate violence respectively.

Article 1 states that; For the purposes of this Declaration, the term "violence against women" means any act of gender-based violence that results in, or is likely to result in, physical, sexual or psychological harm or suffering to women, including threats of such acts, coercion or arbitrary deprivation of liberty, whether occurring in public or in private life. This provision is thus a reiteration of the recognition of domestic violence as an issue requiring state intervention.

Article 2(a) further defines violence in the private sphere as follows; Violence against women shall be understood to encompass, but not be limited to, the following: Physical, sexual and psychological violence occurring in the family, including battering, sexual abuse of female children in the household, dowry-related violence, marital rape, female genital mutilation and other traditional practices harmful to women, non-spousal violence and violence related to exploitation;'. It is noteworthy that the Article does not seek to provide a comprehensive definition, by only 'encompassing' but not 'being limited to' the given description.

The above 2 articles clearly identify three major forms of violence in the private sphere and thereby domestic violence, namely, physical, sexual and psychological. (Subsequent developments have led to the current definition broadening to include economic violence). However the exact acts, which may constitute such abuse, have not been defined and one needs to examine the various international instruments to gain some perspective regarding the scope of these forms of violence. The women's rights set out in Article 3 i.e. rights to life, equality, liberty and security, highest standard possible of physical and mental health, and freedom from discrimination, 
torture and all forms of cruel, inhuman and degrading treatment or punishment, are an echo of the provisions in the UDHR, ICESCR, ICCPR and CEDAW.

Clear indication of the state's role and the intention to bring domestic violence out of the private sphere is seen in Article 4, which declares that 'States should condemn violence against women and should not invoke any custom, tradition or religious consideration to avoid their obligations with respect to its elimination'. This Article provides 17 guidelines states may adopt, in working towards elimination of violence against women in its many forms and in adopting national policies regarding it. These guidelines include enacting domestic legislation, providing effective mechanisms of access to justice, punishment of perpetrators and providing effective remedies for those subjected to violence including, 'rehabilitation, assistance in child care and maintenance, treatment, counselling, and health and social services, ... as well as support structures, and ... measures to promote their safety and physical and psychological rehabilitation.' Article 4 also focuses on the need to sensitize law enforcement and other public officers regarding gender issues and to ensure that laws do not 're-victimize' those subjected to violence by gender insensitive laws, enforcement practices and other interventions. Further, Article $4 \mathrm{~J}$, reiterates State obligations set out in Article 5 of CEDAW discussed above. Thus, Article 4 is a strong indicator of a move away from treating domestic violence as a private matter, and towards one requiring state intervention.

\section{The Beijing Declaration and Platform for Action}

Commitment to the UDHR, CEDAW and the 1993 Declaration was reiterated at the fourth World Conference on Women, held in Beijing China in September 1995. The Beijing Declaration in its 'Platform for Action' deals with violence against women in section $\mathrm{D}$, which adopts the same definitions of violence and sets out similar state obligations as the 1993 Declaration discussed above.

Additionally several articles encompass domestic violence. Article 21 emphasizes the need for prevention and elimination of all forms of violence against women and girls. Article 117 recognizes that acts or threats of violence in the home can create fear and insecurity in women, prevent achievement of equality, and limit women's access to resources. The Article recognizes violence as a 'crucial social mechanism' to put women into a subordinate position to men (which is an echo of the preamble to CEDAW) and continues; '...In many cases, violence against women and girls occurs in the family or 
within the home, where violence is often tolerated. The neglect, physical and sexual abuse, and rape of girl children and women by family members and other members of the household, as well as incidences of spousal and non-spousal abuse, often go unreported and are thus difficult to detect. Even when such violence is reported, there is often a failure to protect victims or punish perpetrators.' Article 117 thus indicates awareness that violence in a domestic setting is viewed as a matter within the private sphere.

Further, Article 18 reiterates the feminist theory regarding violence and continues thus, '...Violence against women throughout the life cycle derives essentially from cultural patterns, in particular the harmful effects of certain traditional or customary practices and all acts of extremism linked to race, sex, language or religion that perpetuate the lower status accorded to women in the family, the workplace, the community and society. Violence against women is exacerbated by social pressures, notably the shame of denouncing certain acts that have been perpetrated against women; women's lack of access to legal information, aid or protection; the lack of laws that effectively prohibit violence against women; failure to reform existing laws; inadequate efforts on the part of public authorities to promote awareness of and enforce existing laws; and the absence of educational and other means to address the causes and consequences of violence. Images in the media of violence against women, in particular those that depict rape or sexual slavery as well as the use of women and girls as sex objects, including pornography, are factors contributing to the continued prevalence of such violence...' This Article too recognizes the pressures to maintain domestic violence within the private sphere and the difficulty to combat such violence in the absence of state intervention.

The declaration then goes on to identify measures that could be taken to prevent violence by addressing the issues highlighted above. Article 119 recommends a 'holistic and multidisciplinary approach' in eliminating violence, including educational systems and socialization processes which focus on equality, respect and mutual cooperation between the sexes.

The Beijing Platform of Action contains strategies to address the issues regarding violence, many in line with the 1993 Declaration. Additionally Article 124 (d) recommends 'access to just and effective remedies including compensation and indemnification and healing to victims and rehabilitation of perpetrators'. Article 125 (a) 
recommends governments to provide 'well-funded shelters and relief support for girls and women subjected to violence, as well as medical, psychological and other counseling services and free or lowcost legal aid, ...(and) appropriate assistance to enable them to find a means of subsistence' while Article 125 (i) recommends that the States, 'Provide, fund and encourage counseling and rehabilitation programmes for the perpetrators of violence and promote research to further efforts concerning such counseling and rehabilitation so as to prevent the recurrence of such violence'. All these recommendations are clearly aimed at promoting state intervention and bringing domestic violence out of the private sphere.

Commitment to the obligations undertaken at Beijing was reiterated in the Political Declaration and outcome document entitled, "further actions and initiatives to implement the Beijing Declaration and Platform for Action" (2000) and by the resolution adopted on the 'Intensification of Efforts to Eliminate Violence against Women' (2008), where obligations were undertaken by Article 16(k) to 'ensure that effective legal assistance is available to all female victims of violence so that they can make informed decisions regarding, inter alia, legal proceedings and issues relating to family law, and also ensuring that victims have access to just and effective remedies for the harm that they have suffered ...'

\section{Conclusions Regarding International Conventions and Treaties}

It is apparent that though there were no specific international documents dealing with domestic violence till the CEDAW Convention, many other documents existed which could have been used to uphold women's rights to a life without violence. Subsequently there has been sustained international concern on the issue of violence against women in its many forms and with specific focus on domestic violence as well. Most of these documents not only reiterate obligations in previous documents, but continue to expand the nature of these obligations as a result of increased awareness of the forms of violence women are subjected to and as various remedies to combat it are recognized. Thus, while the original documents dealt with the core issues alone, later documents expanded to include counseling for victims and perpetrators as well as shelters, legal aid, awareness in family law and the role of the media. It could, therefore, be concluded that these international documents provide a fairly comprehensive coverage of the issues arising with regard to domestic violence. 
Three key themes appear to unite the above instruments, i.e. that domestic violence is primarily a result of the attempt of the male to dominate the females; that cultural and traditional practices are used to maintain the status quo of male domination and retain it within the private sphere; that state intervention is mandatory to eradicate such violence and bring it into the public sphere.

Domestic violence is a predominantly female issue and is the perspective from which this issue is studied. However, it must be recognized that males too may be victims of such violence and that any legislation should, therefore, adopt a gender neutral stance.

Sri Lanka is a signatory to all the above conventions and therefore under an obligation to ensure attainment of these objectives within the country. Therefore, the author intends next to examine the Sri Lankan law in order to identify the extent to which this has been achieved.

\section{The Sri Lankan Legal Regime}

The development of legal provisions to combat domestic violence in Sri Lanka can be seen in the Women's Charter of 1993 and the Prevention of Domestic Violence Act of 2005.

\section{The Women's Charter}

In 1993 Sri Lanka formulated the Women's Charter setting out the state policy regarding women and reiterating obligations undertaken pursuant to international treaties. By Article 16, the State expressed its intention to take measures to prevent violence against women in the family in its many manifestations including rape, physical and mental abuse, and torture and cruel, inhuman or degrading treatment.The National Committee on Women (NWC) was established to monitor the progress in implementing the Charter. This may be seen as the first step towards recognizing the impact of allowing domestic violence to remain in the private sphere and bringing it into the public one. Subsequent to the Beijing Conference, the Ministry of Women's Affairs drew up a National Action Plan (NPA) for women in Sri Lanka on the lines of Platform of Action for Women, recommending actions to eliminate violence against women. However, no significant attempt was made to bring in legislative reform until the enactment of the Prevention of Domestic Violence Act. 


\section{The Prevention of Domestic Violence Act No 34 of 2005}

Specific legislation dealing with domestic violence was not enacted in Sri Lanka until the Prevention of Domestic Violence Act No 34 of 2005. A study of the Act reveals that in reality no new offences were created under it and that the Act once again looks to the Penal Code to identify and punish domestic violence. Since the Act only provides civil remedies the offences identified and punished under criminal law before and after the Act remain unchanged.

What then has been achieved by the passage of the Prevention of Domestic Violence Act? Have the framers of the Act succeeded in bringing domestic violence into the public sphere and created a legal regime which effectively protects those subject to such violence? It is necessary to study the provisions of the act in order to find the answer to these questions. .

\section{The Definition of Domestic Violence under the Act}

Section 23, defines domestic violence as follows; "domestic violence" means $(a)$ an act which constitutes an offence specified in Schedule I (or) (b) any emotional abuse, (either of which is) committed or caused by a relevant person within the environment of the home or outside and arising out of the personal relationship between the aggrieved person and the relevant person'.

The offences identified by schedule 1 of the Act are, all offences contained in Chapter XVI of the Penal Code, extortion (Section 372 of the Penal Code), criminal intimidation (Section 483 of the Penal Code) and attempt to commit the above offences.

The offences set out in chapter XVI of the Penal code are offences affecting the human body, i.e. offences affecting life, causing hurt, wrongful restraint and confinement, criminal force and assault, kidnapping, abduction and slavery, rape and incest and publication of matters relating to certain offences. Each of these headings, deal with several offences.

Offences affecting life are culpable homicide and attempt; murder and attempt to murder; causing death by negligence; abetment to suicide; acts dealing with miscarriage and abandonment and cruelty to children.

Offences relating to causing hurt are; hurt; grievous hurt; hurt by use of weapons; to extort property or to constrain to an illegal act; to 
extort confession or to compel restoration of property; to deter a public servant from his duty; causing hurt on provocation; and causing hurt by an act which endangers life or the personal safety of others.

The offences of wrongful restraint and confinement dealt with in the Penal code include separate offences for wrongful confinement for three or more days and ten or more days; wrongful confinement of a person for whose liberation a writ has been issued; wrongful confinement in secret; and wrongful confinement for the purpose of extorting property, constraining to an illegal act, to extort a confession or compel restoration of property.

Offences of criminal force and assault include sexual harassment; using criminal force to deter a public officer from discharge of his duty; use of assault and force on grave and sudden provocation and assault or force for the following purposes; with intent to dishonour a person without grave or sudden provocation, attempting to commit theft of property carried by a person, in attempting to wrongfully confine a person.

Kidnapping, abduction and slavery deal with the following offences; kidnapping from Sri Lanka and from lawful guardianship; debt bondage, serfdom, forced or compulsory labour, slavery and recruitment of children for use in armed conflict; wrongfully concealing or confining a kidnapped person; kidnapping a child under 10 years with intent to steal movable property from the person of the child; procuration; sexual exploitation of children; trafficking; offences relating to adoption; soliciting a child; cohabitation by inducing belief of a lawful marriage; bigamy; entering into a second marriage by concealing first marriage from second partner; performing a second marriage without intending to enter into lawful marriage; kidnapping or abduction for the following purposes- murder, with intent to secretly and wrongfully confine, to compel a woman to marriage, for subjection to grievous hurt or slavery.

Rape and incest include unnatural offences, acts of gross indecency between persons and grave sexual abuse. The above definition of domestic violence raises several issues. When one compares the Sri Lankan definition with the content of the international documents discussed above, it becomes clear that our law has not adopted a comprehensive approach to identifying and addressing domestic violence. The definition simply adopts wholesale several provisions in 
the Penal Code and as the contents of these provisions indicate, several of these offences do not fit comfortably within the concept of domestic violence. The offences under the Penal Code have been drafted to cover a much broader spectrum of situations including the protection of public officers. Several of the later provisions such as procuration, sexual harassment and trafficking were included as a result of concerns arising at national level. Studies done in Sri Lanka (Gomez, 2006; Gunaratne, 2001; 2007, Hussain, 2000) reveal that the health sector, police and judiciary still do not view domestic violence as a serious issue and the author contends that dealing with this issue using the same provisions as applied in a more general context is likely to lead to the trivializing of the offences occurring in the domestic sphere.

It is also of concern that the Act simply states that 'all offences contained in Chapter XVI of the Penal Code' would constitute acts of domestic violence. Thus, both access to the Penal code and ability to read through this fairly extensive chapter are necessary to identify the scope of the Act. When one considers those to whom the Act is of most concern-the average citizen this seems to place the law outside his/her grasping, reserved for those better versed in the law. A simply expressed comprehensive document would appear to be more suitable for a law that needs wide dissemination and clear understanding.

It is also important to note that for purposes of the Act, rape must be defined as set out in chapter XVI of the Penal Code. The original provisions on rape contained in Sections 363 and 364 of the Penal Code were amended by Penal Code Amendment Act No 22 of 1995. Although this amendment was considered progressive to the extent that it introduced mandatory sentencing and stiffer penalties, the provisions regarding marital rape set out in Section 363 are fairly limited. According to section 363 (b), rape is committed where sexual intercourse occurs 'without her consent even where such woman is his wife and she is judicially separated from the man'. This means forcible intercourse with a woman who is still living with the man or who is 'de facto' as opposed to judicially separated from the man will not be considered as rape. Similarly, Section 363 (e) states that sexual intercourse is rape when done "with or without her consent when she is under sixteen years of age, unless the woman is his wife who is over twelve years of age and is not judicially separated from the man'. As regards married women, this section will only apply to Muslim women since the minimum age of marriage under both the Kandyan law [by virtue of Section 6 of the Kandyan Marriage and Divorce Act as amended by Section 3 of Amendment No 19 of 1995] 
and general law [by virtue of Section 15 of the Marriage Registration Ordinance 1907 as amended by Section 2 of the Amendment No 18 of 1995] is eighteen years. However there is no protection under the Penal Code or the Act for a Muslim wife even a day over twelve who is forced into sexual intercourse by her husband. It is noteworthy that the original Amendment had a broader definition which was narrowed due mainly to protests from the Muslim lobby and which appears to be in direct conflict with Article 4 of the 1993 Declaration. However, it is a serious deficit when an Act designed to prevent domestic violence defines marital rape in such a narrow manner. Such a definition denies married women relief for one of the commonest forms of domestic violence and reinforces the belief that such acts are retained within a private sphere beyond state intervention.

Section 23 of the Prevention of Domestic Violence Act defines emotional abuse as 'a pattern of cruel, inhuman, degrading or humiliating conduct of a serious nature directed towards an aggrieved person'. The use of the term 'conduct of a serious nature' gives rise to some concern. Issues arise as to who decides what is 'serious' and how it is decided. In addition, how is the word 'pattern' defined? Does this mean that emotional abuse can only take place if it is continuous and if so how many events are necessary to establish a 'pattern'? It is doubtful if applying the usual 'reasonable man' test would be acceptable, in the light of the prevailing attitudes among the law making and implementing authorities.

It is also noteworthy that financial or economic abuse is not encompassed within the definition of domestic violence. While some acts of economic abuse may arguably be brought within the definition of emotional abuse as 'a pattern of degrading and humiliating conduct', not all such acts would fall within this and it is also uncertain if such acts would be considered 'serious' or indicative of a 'pattern' as is required by the definition. As Radika Coomaraswamy has commented to Sathkunthanathan (2005) the definition for domestic violence in the Act has failed the test of 'broadest possible definition of acts of domestic violence' which is the recommended standard. Thus, a more comprehensive and clear definition for domestic violence should have been adopted in the Act. The author argues that the vagueness of the definition itself may act as an impediment in bringing to task persons who commit domestic violence and thus place such acts beyond state intervention. 


\section{Is Domestic Violence a Crime?}

As stated earlier, although domestic violence has been defined in the Act, no new offence is created by the Act itself. The whole thrust of the Act is on the creation of Protection Orders. Section 23 of the Act states that aggrieved persons would continue to have the right to institute civil or criminal proceedings. In order to do so, one would have to access the normal civil and criminal laws. Thus, police may prosecute the abuser under the relevant provisions of the Penal Code cited above or any other applicable provisions of the Penal Code to obtain a conviction with fine or imprisonment; alternatively the abused person could bring civil action in order to obtain compensation. Thus, the only remedy a person is provided by the Act is a Protection Order against future violence and no means for obtaining relief or compensation for abuse already suffered is provided under it.

The author argues that the law should create a separate crime titled, 'domestic violence' so that perpetrators' can be prosecuted for 'domestic violence' itself instead of being prosecuted for an act committed in breach of the general provisions of the Penal Code. This is likely to be a more effective deterrent to perpetrators and place responsibility for its eradication more firmly on the state and in the public sphere.

\section{Protection Orders}

The Act contains comprehensive provisions regarding Protection Orders. A welcome feature of the Act is the gender neutrality of the provisions which therefore entitle not only women but also men to the protections afforded by the Act. The Act under Section 23 also recognises a wide range of persons against whom such protection maybe sought. These include the spouse, ex-spouse or co-habiting partner as well as the father, mother, grandfather, grandmother, stepfather, stepmother, son, daughter, grandson, granddaughter, stepson, stepdaughter, brother, sister, half-brother, half-sister, step brother, step-sister, siblings of a parent, child of a sibling, child of a sibling of a parent (of the aggrieved person, or his/herspouse, former spouse or cohabiting partner). Thus, the act protects against both marital and non marital partners and well as against a range of relatives of both the abused person and his or her partner or former partner.This broad definition is capable of covering most circumstances in which domestic violence occurs and is thus a salutary feature. 
A number of persons are given 'standing' to apply for Protection Orders by virtue of Section 2 (2) of the Act. Therefore not only the aggrieved person, but also a police officer is entitled to file for such order. As regards a child, a guardian, parent, person with whom the child resides or officer of the National Child Protection Authority may also do so. This is a positive aspect of the Act, as it recognises that a person maybe caught up in the cycle of domestic violence and unable to escape it. It also recognizes that the state should play a role in protecting persons subject to violence in the private sphere and provides for proactive state intervention.

Speedy hearing of the application is contemplated by Section 4 of the Act which provides for the application to be heard within two weeks. However, Gomez (2006) argues that this time period is inadequate, especially when the whereabouts of the offender is unknown, as magistrates insist on a probation officer's report before issuing an order. Pending the hearing, the Magistrate's court also has jurisdiction to issue Interim Protection Orders if it is deemed necessary for the safety of the aggrieved person and this Order would remain in force till it is vacated or replaced with a Protection Order. The order could include prohibitions against committing acts of violence as well as the prohibitions and conditions included in a Protection Order. Further, the court could order the parties to attend counseling sessions with a social worker or family counselor and also appoint such persons as well as probation officers, family health workers or child's rights protection workers to monitor and report on the observance of the order.

After hearing the application, the court may issue a Protection Order preventing the person from committing acts of violence as well as setting out other prohibitions and supplementary orders. The prohibitions which may be imposed are contained in Section 11 and are as follows; prohibits entering or occupying a shared residence or a specified part of it; entering the aggrieved person's, residence, workplace, school, or place of shelter; prohibits prevention of the aggrieved person from entering or remaining in the shared residence; prohibits or lays down conditions with regard to contacting children; prohibits preventing use or access to shared resources; prohibits contact or attempt to contact aggrieved person; prohibits acts of violence against 'Other Persons' (relative, friend, social worker or medical officer) assisting the aggrieved person; prevents following the person or engaging in conduct detrimental to the safety, health or well being of the aggrieved or Other Person; prevents selling, 
transferring, alienating or encumbering the matrimonial home thereby placing the aggrieved person in a destitute position.

Once a Protection Order is made, the court could also make the following orders as set out in Section 12 for the immediate safety, health and welfare of the aggrieved person; order the police to seize any weapons in the respondent's possession; order police to accompany the aggrieved person to any place to assist with the collection of personal property of such person and his/her children; order the two persons to attend mandatory counseling sessions, psychotherapy or other forms of rehabilitative therapy; order temporary accommodation/shelter for the aggrieved person while maintaining confidentiality as to location; order a social worker, family counselor, probation officer or family health worker to monitor the observance of Order and submit a report every three months; if the respondent owes a duty of support to the aggrieved person order to provide urgent monetary assistance or to pay and provide facilities for residence of aggrieved party depending on the resources and needs of the parties. The parties' rights under the Maintenance Act remain unaffected by these provisions and in the event of non-payment dues could be claimed direct from the respondent's employer.

As seen, above Sections 10-12 contain the relief available to a survivor of domestic violence. These are aimed at protecting the person from further abuse and providing for him/her. The Protection Order is issued for a maximum of one year and can on subsequent application be extended, varied or revoked. There is also provision to appeal from the order. Another salutary feature is that once an Order is made a copy of it is provided to the Officer in Charge of the police stations in the area where both the aggrieved person and respondent reside. This provision could be used to ensure a more proactive role by police in the protection of the aggrieved person.

However, Sathkunthanathan (2005) noted several shortcomings in this regard at the Bill stage of the Act which remained unaddressed in the final Act. These include the absence of provisions requiring medical service providers to report abuse, the absence of provisions dealing with the manner in which police should respond to complaints of violence and absence of services and treatment for victims including crisis centres and medical care. Gomez (2006) too noted shortcomings with regard to implementing the Act; magistrates' trivializing issues of domestic violence due to regularly handling more 'serious' offences like murder; absence of family counsellors in some courts, even though required by the Act, 
absence of state shelters or temporary accommodation (only WIN, Welcome Home and the Salvation Army have such shelters and magistrate's are reluctant to refer women to these shelters due to reasons of accountability). Gomez suggested the following as requirements to ensure proper implementation of the Act; public awareness and training of state officers; active participation of all stake holders, i.e. police, medical personnel, social workers, probation officers, civil society groups, women's organisations, lawyers, judiciary, family counsellors and victims of domestic violence; and implementation of the National Action Plan prepared by the National Committee on Women.

The shortcomings highlighted above indicate that few of the guidelines in Article 4 of the 1993 Declaration and Article 18, 124 and 125 of the Beijing Declaration have been included in the Act and that there are difficulties to implement those few which are included in the Act, due to lack of basic infrastructure and facilities. It also raises questions as to how successful the Act has been in bringing domestic violence into the public domain.

\section{Penal Sanctions}

The only two penal sanctions in the entire Act are to be found in Sections 18 and 20. According to Section 18, failure to comply to an Order could lead to a fine not exceeding ten thousand rupees or imprisonment for up to one year or both fine and imprisonment. Section 20 lays down a fine, imprisonment of up to two years or both fine and imprisonment for anyone who prints or publishes the name or information enabling identification of any party to an application under the Act or who prints or publishes anything other than a judgment of the Supreme Court or Court of Appeal.

The above two provisions appear to be aimed at ensuring compliance of the Orders made under the Act and protecting the confidentiality of parties involved in such applications respectively. In practical terms enforcement of these sections could lead to a situation where a person who publishes details of a respondent maybe imprisoned for two years, while if that respondent fails to observe the order, he may be imprisoned for one year only. While a maximum fine has been set out under section 18, there is no such limitation under section 20. Another issue is the wide discretion provided in determining punishment, due, as Gomez (2006) has noted, to the absence of mandatory sentences. In a legal system where rapists have been handed down suspended sentences, it is arguably not in 
the best interests of the person abused to leave discretion which may limit punishment to a maximum of ten thousand rupees.

Protection of the identity of someone subjected to violence maybe a salutary feature. However, it is difficult to comprehend a law by which a person who publishes information regarding an abuser, maybe subjected to more severe punishment than the abuser himself. Such protection could also place others who may unknowingly enter into intimate relationships with such persons in grave danger of violence.

Sathkunthanathan (2005) identified lack of enhanced penalties in cases of repeat offenders and in instances of aggravated assault and use of weapons as shortcomings of the Act while there were also suggestions that provision should be made for suspended warrants of arrest in case of violation of protection orders.

Therefore, the penal provisions in the Act appear to be drafted so as to minimize harm and protect the social image of an abuser - most likely a male. This seems to substantiate the feminist argument that patriarchal values underlie legal provisions.

\section{Conclusions}

The above analysis indicates that domestic violence, through the passage of time, has gradually come to be recognised as a matter requiring state intervention. International concern about this issue is seen by the various treaties and conventions which continue to reiterate and broaden obligations of member states towards elimination of domestic violence as well as helping those subjected to abuse and rehabilitating offenders. Thus, at international level, it is accepted that women are entitled to the gamut of recognised rights including a right to be free of violence. Recognition that male dominance as well as cultural and social practices perpetuate violence and need to be eliminated has also been emphasised. In the Sri Lankan context, while the Prevention of Domestic Violence Act must be hailed for introducing legal recognition regarding domestic violence and for the introduction of protection orders, the Act itself as discussed above, has many shortcomings commencing with the inadequate definition of domestic violence.

It is also significant that domestic violence has not been made a crime to date. The Prevention of Domestic Violence Act only affords protection to the abused person and no punishment except in the 
case of violation of a protection order. The passage of the Act through Parliament was dogged by arguments that it was a western concept contrary to Sri Lankan culture and family values. These attitudes reflect provisions in CEDAW and the Beijing Declaration that tradition is used to perpetuate violence. It is also an affirmation that patriarchal values are deep rooted in society and that female subordination is viewed as a traditional value that needs to be protected. Attempts to allay fears about the Act led to emphasis being placed on the fact that the Act did not criminalize the perpetrators and was only meant to protect the victims. This, coupled with the fact that it is nevertheless possible to institute civil or criminal proceedings independent of the Act, seems to emphasise the intention of legislators to ensure that acts of violence cannot be punished as 'domestic violence'. This then enables legislation to leave violence which is 'domestic violence' within the private domain.

The deficiencies in mechanisms to effectively implement and enforce the protections provided in the Act too, raise concerns as to whether the Act has succeeded, in bringing domestic violence out of the private domain in its true sense. While putting in place relevant legislation is a key part of this process, the absence of effective mechanisms to implement the provisions, raise awareness and sensitize relevant authorities may lead to it having little value in a society still steeped in patriarchal values. Of what value is a protection order, if a battered woman has nowhere to hide and the police fail to take her complaints seriously? Therefore, it may be concluded that though laudable efforts have been made to bring the Sri Lankan woman subjected to domestic violence out of the private sphere, and give her story a public voice, much more state intervention is required to enable her voice to be heard forcefully and justifiably.

\section{References}

Beijing Declaration and Platform of Action 1995

Blackstone, W. (1765) Commentaries on the Law of England Vol. 1, in Harris Short, S. and Miles, J. (2007) in Family Law, Texts, cases and Materials, Oxford, Oxford University Press

Convention on the Elimination of All Forms of Violence against Women (CEDAW) 1979 
Council of Europe Convention on Preventing and Combating Violence against Women and Domestic Violence (The Istanbul Convention) of $11^{\text {th }}$ May 2011

Davies v Johnson [1979] AC 264, 270

Declaration on the Elimination of All Forms of Violence against Women 1993

Dalton, C. (1987) Where We Stand; Observations on the Situation of Feminist Legal Thought, Berkeley Women's LJ3, (1) 1-13 available at http://scholarhip.law.berkerey.edu/bglj/vol3/iss 1/1

Economic and Social Council resolution 1990/15 of 24 May 1990

Economic and Social Council resolution 1991/18 of 30 May 1991

Further Actions and Initiatives to Implement the Beijing Declaration and Platform for Action, 23rd Special Session of UN General Assembly on "Women 2000: gender equality, development and peace for the twenty-first century" June 2000

Freeman, M. D. A. (2008) Lloyd's Introduction to Jurisprudence, London, Thomson Reuters

Gomez, S. (2006) Sri Lankan New Law on Domestic Violence; Ensuring Implementation. Forum News May/August, 19/ 2, 26-27

Gunaratne, C. (2001) 'Domestic Violence a Case Study of Sri Lanka' at the Expert Meeting -Zero Tolerance for Domestic Violence Asian Women's Fund, Tokyo, Japan, August 7-9

Hale, M. (1736) History of the Pleas of the Crown in Harris Short, S and Miles, J. (2007) in Family Law, Texts, cases and Materials, Oxford, Oxford University Press

Hussain, A. (2000) Sometimes there is no blood: Domestic Violence and Rape in Sri Lanka ICES Colombo.

International Covenant on Civil and Political Rights (ICCPR) 1966 
International Covenant on Economic, Social and Cultural Rights (ICESCR) 1966

Kandyan Marriage and Divorce Act No 44 of 1952

Kandyan Marriage and Divorce (Amendment) Act No 19 of 1995

Marriage Registration Ordinance No 19 of 1907

Marriage Registration (Amendment) Act No 18 of 1995

McColgan, A, (1993) In Defence of Battered Women Who Kill. Oxford Journal of Law Studies, 13, 508

Lacey, N. (1998) Unspeakable Subjects: Feminist Essays in Legal and Social Theory, Oxford Hart Publishing, Penal Code No 2 of 1883 (as amended)

Penal Code Amendment Act No 22 of 1995

Prevention of Domestic Violence Act No 34 of 2005

Resolution on the Intensification of Efforts to Eliminate Violence against Women, 63 ${ }^{\text {rd }}$ Session of the UN General Assembly, December 2008

Questions and Answers Regarding the Prevention of Domestic Violence Bill (briefing Paper prepared by the Council of Justice and Judicial Reform) (2005) LST Review 15/210 April

Sathkunthanathan, A. (2005) Analysis of the Prevention of Domestic Violence Bill. LST Review, 15/210 April

Universal Declaration on Human Rights 1948

Women's Charter (Sri Lanka) 3rd March 1993

Received: 30-4-2015 Revised: 17-7-2015 Accepted: 03-8-2015 